\title{
Robin Wilkinson
}

\section{The PM}

Everyone says the PM's a top bloke. The sort you wouldn't mind sharing a beer or friendly wrestle with. He's the longest PM we've ever had: over three metres from nose to tail, the deadliest at close range. The PM commands respect. When he speaks the country listens. It was the PM who brought in the brokers for a bollocking, who sandbagged the borders, who went to the front and stuck it to the Afrasians. The PM never shirks a blue. When he shoots, it's a straight shot. If the PM says that we're removing the hawsers of fiscal something for somewhere across these economic seas, you know that he means whatever it is that he means.

'What is it that the PM means?' asks the Missus, perched in the window.

'Tinny?' I ask.

'Will he physically unmoor the country? Is he that strong?'

'He can do whatever he wants. That's what we put him there for. Jeez.' I place a can next to her on the sill. The Missus faces outside, soaking up the sunshine and watching the parade below. She has her back towards me. She's a good woman with a good back. I like a woman with a good back so long as she's not too proud. One thing I don't like though, is when the Missus asks too many questions. It prickles my skin and makes me edgy. 'We should go down soon.'

On the wall, our meedya screens the parade. I can see everything the Missus can, but from a different angle. Our meedya's the length of one wall and is the envy of our neighbours. I watch the passing floats and banners, athletes with their displays of football prowess, servicemen and CWA Auxiliaries leading the jet-black limousine at the centre of it all. They're cheered on by a crowd ten deep, decked out in the unmottled colours of the nation. 
What is it about the PM that makes us feel a million bucks? It's hard to explain to other folk. Outsiders, I mean. I reckon people are pretty laid back most of the time, but the sight of the PM standing tall in his chitin, you feel it in your guts. It was the PM who gave us the freedom to feel good about ourselves. People used to worry too much about stuff; the PM says we're entitled to not give a fuck. That's what life's about. And it's because of him that we don't have to care about death, philosophy or any of those other big things in life. So today we get to honour all that and thank the PM for being our PM.

I love the Missus but I can't tell her all this. She can't let go of things. She likes to push my buttons with strange questions like 'who was PM before the PM?' As if it matters. When she goes on like this my head is all muddled and the words get stuck in my mind and spin round till I can't talk straight no more. I swear sometimes she drives me nuts.

Here's some facts you ought to know about the PM: he never graduated; he's working class; he's a Rhodes scholar; he's his own man; he's a ladies man; he's one of the boys; he can scull a yard glass in under a minute and strip a rifle in less than twenty seconds; he's a reformed alcoholic and his best figures are 5-23 (left-hand unorthodox).

A cheer rises from the crowd on the street. Coming through the window and broadcast off the meedya it's a distorted stereo. The vanguard of bikies has come into view; those rough nuts always get a rise from the kids.

I knock back the tinny. 'Righto!' Grabbing the Missus by the hand I start to lead her down outside and into the parade, but she pulls back at my grip.

'I'm not sure,' she says. She looks worried but then again she always does. I can see the question forming on her lips. 'Will it be okay?'

'Why not?'

'It might be dangerous.'

'She'll be right,' I burp. It's difficult to tell if she's serious or not. 'Now's not the time for games, love.' I tug her towards the door. She resists, but then after a second, her small body goes limp and she comes along. 
The crowd is thick and sweaty, arseholes and elbows as far as the eye can see. It smells of hot bodies and hot chips - salt and vinegary. We push our way through the throng for a better vantage point. Giant meedya on the sides of buildings screen the event for those in the back, but we want to see the action with our own eyes. To be at the front when he comes.

Every country has its day but thanks to the PM we have ours everyday. That might strike you as odd but why should we pat ourselves on the back only once a year? Each day, a new city or town gets the opportunity to be the centre of the nation, the site of a great party which never stops. Last night when they did the draw I swear I nearly had a heart attack. We called in all the neighbours to watch the replay on our new meedya and we sank a few tinnies to celebrate. Who knows when we'll next have a go.

The anthem starts up, which is the signal that he's about to arrive. The music settles the crowd a bit. It makes you feel dopey: your date unclenches and you get a warm buzz in your gut. They say it's better to see the PM when you're in a nice relaxed state. I can feel the Missus' hand become soft and droopy in mine. Even she can't resist him.

The PM's black limo rounds the corner of the boulevard and comes to a slow stop halfway down. Everyone in the crowd inhales with anticipation. The anthem continues to play while the meedya shows a montage of the PM: there he is signing bills with an ink-wet talon; test-loading artillery on the frontline; basking on a rock before a group of foreign dignitaries.

The rear left door of the limo swings open and the PM's sweaty funk exudes, spreading out across the parade. They use it as a nerve gas on the front, as it's deadly in high concentrations. Even from this distance it's potent. A thick, solid leg emerges from the limo and plants itself on the ground, followed by another and then the rest of the PM's enormous bulk. The PM stands erect, exposing rows of sharp teeth, his blubber contained by a dark carapace. He rears above us in all his glory. 
Suddenly the crowd surges forward around me and I find I'm carried along with it. I lose grip of the Missus' hand but I don't mind. She's pushed along by the pack and soon enough she's pushing along with it too. I don't even care when I lose track of her.

Up ahead, the crowd rushes at the PM and bowls the poor bastard over in its momentum. I can see the PM for a second and then he's gone, underneath all those bodies. They swarm over him in their unmottled colours, burying him in yellows and whites. I can feel my heart beating strong and I heave a little with excitement; I can't wait to have a crack. I get a bit worried that I might miss out but somehow I keep getting moved onwards. The crowd's like a huge swell, pushing forward and back but each time we get a little closer. It's like we all know what to do without having to think about it.

Still, I'm scrabbling at people's backs and trying to push my way through, when I'm suddenly propelled into a clearing surrounding the enormous hulk of the PM. He's lying on his back and his exposed stomach has been torn open, white flesh gleaming beneath the soft hide. The PM's head is hidden behind his expansive bulk. He is unmoving, lifeless. Someone shoves me hard in the back and I fall to my knees, before his belly. Instinctively, I lean in and plunge my hands deep into the folds of that wet, white flesh and scoop out a handful of meat, shovelling it into my mouth. It has the texture of fish, the taste of chicken. It's greasy and sticky and clings to my hands and face. I can't even chew. I'm just swallowing huge mouthfuls of the stuff and each gulp goes right through me, warms me up, makes my balls swell and my head feel like the back half has been ripped open. I lean in for another scoop. A large taloned hand grasps me by the back of the neck and pushes my face into the PM's gut. The flesh goes up my nose and down my throat; I can't breath but I don't resist. Under my skin I can feel the PM's internal fluids pumping; his ichor smells of gunshot and his grease clings to my hair. The PM holds me there while I imbibe his body. His essence surges through me: I become the PM. I feel the weight of the burden he carries, the enormity of the decisions he makes on our behalf, taking the consequences so we don't have to. 
The pressure of being the PM is more than any one individual can bear, but he takes it all on because he loves us; so that we don't have to worry about the big, stupid stuff. All this is mine to fathom.

The PM pulls me up for air and I go to dive in for a third shot, but somebody grips my shoulders and pulls me out the way. Someone else dives in, taking my place within the folds of meat. I am whisked out from the centre of the pack, back towards the periphery and the PM is lost to me once more.

Shortly after, I find the Missus sitting on a kerb, away from the commotion. Her gaze is distant, dazed; she's covered in bits of white meat and her lips shine with a film of grease.

She looks at me and opens her mouth to speak.

'Don't spoil it. You understand now.'

The Missus nods.

By the time we get up to our pad, the crowd has dispersed and the street is empty. There is no sign of the PM, or his limo and they're cleaning the streets. I close the window and pull down the blinds, while the Missus dozes in front of the meedya.

Truth is, I feel washed out too. I could do with a kip and a tinny before the evening news. They say that after tonight's draw, the PM's going to make an important announcement. 